\title{
PENGARUH SHOPPING LIFE STYLE DAN FASHION INVOLVEMENT TERHADAP IMPULSE BUYING BEHAVIOR MASYARAKAT HIGH INCOME SURABAYA
}

\author{
Edwin Japarianto dan Sugiono Sugiharto \\ Fakultas Ekonomi, Universitas Kristen Petra \\ Jl. Siwalankerto 121-131, Surabaya 60236 \\ Email: edwinj@petra.ac.id; sugiono@petra.ac.id
}

\begin{abstract}
Abstrak: Dinamika perekonomian bisnis ritel di Indonesia menunjukkan pertumbuhan yang signifikan, sehingga akan memicu perkembangan gaya hidup dan pola belanja masyarakat (konsumen) yang memiliki ekspektasi makin tinggi, meminta lebih banyak, menginginkan kualitas yang lebih baik dan konsisten. Permasalahan yang dihadapi, komsumen high income menunjukkan pola pengeluaran belanja yang fluktuatif, sering kali melesat dari perencanaan keuangan yang telah dibuat. Penelitian ini bertujuan untuk membuktikan pengaruh shopping life style dan fashion involvement terhadap perilaku impulse buying pada masyarakat high income Surabaya. Penelitian ini menggunakan sampel yang tinggal di Surabaya, memiliki pendapatan sendiri, memiliki pengeluaran $\geq R p$ 1,250,000.00, pernah berbelanja di Galaxy Mall , Lendmarc dan Grand City. Teknik analisis yang digunakan adalah Regresi Linier berganda, yang akan mempermudah untuk melihat peranan Shopping lifestyle dan fashion involvement terhadap perilaku impulse buying yang akan diuji. Hasil pengujian menunjukkan bahwa Hedonic Shopping Value dan Fashion Involvement berpengaruh terhadap perilaku Impulse Buying pada Masyarakat High Income Surabaya.
\end{abstract}

Kata kunci: shopping life style, fashion involvement, impulse buying.

Abstract: Dynamics of the retailing business economy in Indonesia develop rapidly, so that it triggers the customers' shopping lifestyle and their fashion involvement as well. They have higher expectation, demand more and desire better quality product consistently. But in the other side there are some problems. For instance the prosperity consumers spend their money fluctuatively and oftenly out their financial plan. The purpose of this research is proving, whether shopping lifestyle and fashion involvement will influence the impulse buying behavior of Surabaya's high income community. As sampling, this study used the population of Surabaya that usually spend their money more or equal to Rp.1.250.000 per month, and ever go shopping at Galaxy mall, Lendmarc and Grand City. The technical analysis to examining the role of shopping lifestyle and fashion involvement toward the impulse buying behavior is Multi linear Regression. The examination result showed that Hedonic Shopping Value and Fashion Involvement influenced the Impulse Buying Behavior of Surabaya's High Income Society.

Kaywords: shopping life style, fashion involvement, impulse buying.

\section{PENDAHULUAN}

Seiring dengan perkembangan jaman yang semakin modern menyebabkan banyaknya pembangunan mall atau shopping centre. Indonesia Tourism News melansir bahwa kehadiran mall di Surabaya telah mengukuhkan jati diri sebagai kota perdagangan. Selain itu, dengan kehadiran mall diharapkan dapat menjadi daya tarik wisata. Kini Surabaya telah memiliki setidaknya 32 shopping mall dan diperkirakan akan terus bertambah tiap tahunnya. Kelahiran shopping mall di Surabaya diawali dengan adanya Tunjungan Plaza, yang disusul Delta Plaza dan Surabaya Mall pada tahun 1986. Kehadiran tiga shopping mall tersebut secara perlahan diikuti pusatpusat perbelanjaan modern lainnya hingga mencapai booming pada periode tahun 2005-2008 (Indonesia Tourism News, 2008). Bertambahnya shopping centre di Surabaya dari tahun ke tahun menjadikan peluang bisnis bagi para pelaku bisnis terutama dibidang fashion karena banyak pengunjung yang berkunjung ke shopping centre, dimana sebagian besar pengunjung yang berkunjung karena ingin berbelanja pakaian. Fenomena tersebut menyebabkan kebanyakan mall yang ada menjual berbagai jenis fashion baik untuk pria maupun wanita yang berada di boutique, factory outlet ataupun di department store yang mempunyai fasilitas pelayanan dan mutu yang sesuai dengan standart yang diterapkan tiap toko. Fashion adalah jenis tenant utama dari sebuah shopping centre atau mall, berupa toko baju anak, pria dan wanita yang berbentuk butik atau ready-to-wear, termasuk toko aksesoris dan kosmetika (Indonesia Shopping Centers, 30 Januari 2009), ketika melihat pakaian yang dipajang di etalase toko yang menarik menurut pengunjung tersebut maka pengunjung tadi akan membeli pakaian yang di inginkan meskipun harus mengeluarkan uang lebih demi mendapatkan pakaian 
yang diinginkan. Pernyataan tersebut di dasari oleh persentase masyarakat Surabaya yang datang berkunjung di mall untuk berbelanja sebesar 51\% dibandingkan aktivitas lainnya ("29 Proyek Manantang Krisis Global", Maret 2009).

Bagi masyarakat high income berbelanja hal yang sudah menjadi lifestyle mereka adalah mereka akan rela mengorbankan sesuatu demi mendapatkan produk yang mereka senangi. Hal tersebut didukung dengan survey yang dilakukan penulis dengan ditemukannya $94 \%$ masyarakat Surabaya yang high income lebih sering berbelanja di mall high class dibandingkan dengan mall lainnya. Hal ini didukung dengan pernyataan Leon Tan yang mengatakan bahwa "bayang-bayang resesi global, baik secara langsung atau tidak langsung, ikut mempengaruhi pola berpikir dan lifestyle kita, termasuk dalam cara berbelanja. Bagaimanapun, krisis tak berarti harus menghentikan aktivitas shopping lifestyle kita". (Tan, 2009, p. iii)

Masyarakat high income akan membeli pakaian yang sedang dicari dengan harga, kualitas, serta mode yang diinginkan. Pernyataan tersebut didukung oleh hasil pra penelitian yang dilakukan oleh penulis dengan menemukan bahwa masyarakat high income yang berkunjung cenderung berbelanja pakaian (94\%), sepatu (71\%), tas (55\%), elektronik (33\%), acceccoris (10\%). Kecenderungan perilaku seperti ini merupakan peluang yang ditangkap para pemilik tenant untuk menjual pakaian yang di senangi oleh para pengunjung yang berasal dari masyarakat high income yang lebih mementingkan kualitas, model, merk daripada harga yang tercantum adalah fashion involvement yang terjadi

Ketika masyarakat dari kelas high income melihat produk yang sulit dicari ditemukan maka ia akan membeli produk tersebut meskipun ia tidak merencanakan pembelian tersebut yang menyebabkan terjadinya impulse buying,

Dari latar belakang tersebut rumusan masalah yang diambil adalah: Apakah shopping lifestyle dan fashion involvement berpengaruh terhadap impulse buying behaviour pada masyarakat high income di Surabaya?

\section{TINJAUAN PUSTAKA}

\section{Shopping Lifestyle}

Shopping lifestyle mengacu pada pola konsumsi yang mencerminkan pilihan seseorang tentang bagaimana cara menghabiskan waktu dan uang. Dalam arti ekonomi, shopping lifestyle menunjukkan cara yang dipilih oleh seseorang untuk mengalokasikan pen- dapatan, baik dari segi alokasi dana untuk berbagai produk dan layanan, serta alternatif-alternatif tertentu dalam pembedaan kategori serupa (Zablocki dan Kanter, 1976, p. 269-297).

Cathy J. Cobb dan Wayne D. Hoyer (1986) mengungkapkan bahwa konsumen diminta untuk menunjukkan sejauh mana mereka sepakat atau tidak setuju dengan pernyataan yang berkaitan dengan shopping lifestyle (misalnya, sikap terhadap merk nasional, dirasakan pengaruh iklan, harga kesadaran).

Betty Jackson (2004) mengatakan shopping lifestyle merupakan ekspresi tentang lifestyle dalam berbelanja yang mencerminkan perbedaan status sosial.

Cobb dan Hoyer (1986) mengemukakan bahwa untuk mengetahui hubungan shopping lifestyle terhadap impulse buying behavior adalah dengan menggunakan indikator:

- Menanggapi untuk membeli setiap tawaran iklan mengenai produk fashion

- Membeli pakaian model terbaru ketika melihatnya di Galaxy Mall

- Berbelanja merk yang paling terkenal

- Yakin bahwa merk (produk kategori) terkenal yang di beli terbaik dalam hal kualitas

- Sering membeli berbagai merk (produk kategori) daripada merk yang biasa di beli

- Yakin ada dari merk lain (kategori produk) yang sama seperti yang di beli

Berdasarkan beberapa definisi di atas, dapat disimpulkan bahwa shopping lifestyle adalah cara seseorang untuk mengalokasikan waktu dan uang untuk berbagai produk, layanan, teknologi, fashion, hiburan dan pendidikan. Shopping lifestyle ini juga ditentukan oleh beberapa faktor antara lain sikap terhadap merek, pengaruh iklan dan kepribadian.

\section{Fashion Involvement}

Menurut O'Cass, involvement adalah minat atau bagian motivasional yang ditimbulkan oleh stimulus atau situasi tertentu, dan ditujukan melalui ciri penampilan (O'Cass, 2004 dalam Park 2005). Sedangkan menurut Zaichkowsky, involvement didefinisikan sebagai hubungan seseorang terhadap sebuah objek berdasarkan kebutuhan, nilai, dan ketertarikan (Zaichkowsky, 1985, pp. 341-352).

Involvement dapat dipandang sebagai motivasi untuk memproses informasi (Mitchell, 1979, pp. 191196). Selama involvement meningkatkan produk, konsumen akan memperhatikan iklan yang berhubungan dengan produk tersebut, memberikan lebih banyak upaya untuk memahami iklan tersebut dan 
memfokuskan perhatian pada informasi produk yang terkait di dalamnya, di sisi lain, seseorang mungkin tidak akan mau repot untuk memperhatikan informasi yang diberikan (Celsi dan Olson, 1988, pp. 210-224). Begitu pula dengan fashion, banyak orang terlibat dengan fashion, menghabiskan waktu dan uang untuk gaya terbaru, sedangkan yang lain (sering kali pria memenuhi syarat di kategori ini) menemukan bahwa berbelanja pakaian adalah sebuah tugas.

Dalam pemasaran fashion, fashion involvement mengacu pada ketertarikan perhatian dengan kategori produk fashion (seperti pakaian). Fashion involvement digunakan terutama untuk meramalkan variabel tingkah laku yang berhubungan dengan produk pakaian seperti keterlibatan produk, perilaku pembelian, dan karakteristik konsumen (Browne and Kaldenberg, 1997; Fairhurst,1989; Flynnand Goldsmith, 1993 dalam Park 2006). Sebagai contoh, O'Cass (2004) dalam Park (2006) menemukan bahwa fashion involvement pada pakaian berhubungan sangat erat dengan karakteristik pribadi (yaitu wanita dan kaum muda) dan pengetahuan fashion, yang mana pada gilirannya mempengaruhi kepercayaan konsumen di dalam membuat keputusan pembelian. Dalam Kim (2005) mengemukakan bahwa untuk mengetahui hubungan fashion involvement terhadap impulse buying behavior adalah dengan menggunakan indicator:

- Mempunyai satu atau lebih pakaian dengan model yang terbaru (trend)

- Fashion adalah satu hal penting yang mendukung aktifitas

- Lebih suka apabila model pakaian yang digunakan berbeda dengan yang lain

- Pakaian menunjukkan karakteristik

- Dapat mengetahui banyak tentang seseorang dengan pakaian yang digunakan

- Ketika memakai pakaian favorit, membuat orang lain tertarik melihatnya

- Mencoba produk fashion terlebih dahulu sebelum membelinya

- Mengetahui adanya fashion terbaru dibandingkan dengan orang lain

Berdasarkan beberapa definisi di atas dapat disimpulkan bahwa fashion involvement adalah keterlibatan seseorang dengan suatu produk pakaian karena kebutuhan, kepentingan, ketertarikan dan nilai terhadap produk tersebut. Dalam membuat keputusan pembelian pada fashion involvement ditentukan oleh beberapa faktor yaitu karakteristik konsumen, pengetahuan tentang fashion, dan perilaku pembelian.

\section{Impulse Buying}

Pemahaman tentang konsep pembelian impulsif (impulse buying) dan pembelian tidak direncanakan (unplanned buying) oleh beberapa peneliti tidak dibedakan. Philipps dan Bradshow (1993), dalam Bayley dan Nancarrow (1998) tidak membedakan antara unplanned buying dengan impulsive buying, tetapi memberikan perhatian penting kepada periset pelanggan harus memfokuskan pada interaksi antara point-of-sale dengan pembeli yang sering diabaikan. Engel dan Blacwell (1982), mendefinisikan unplanned buying adalah suatu tindakan pembelian yang dibuat tanpa direncanakan sebelumnya atau keputusan pembelian dilakukan pada saat berada di dalam toko. Coob dan Hayer (1986), mengklasifikasikan suatu pembelian impulsif terjadi apabila tidak terhadap tujuan pembelian merek tertentu atau kategori produk tertentu pada saat masuk ke dalam toko. Beberapa peneliti pemasaran beranggapan bahwa impulse sinonim dengan unplanned ketika para psikolog dan ekonom memfokuskan pada aspek irasional atau pembeli impulsif murni (Bayley dan Nancarrow, 1998).

Keputusan pembelian yang dilakukan belum tentu direncanakan, terdapat pembelian yang tidak direncanakan (impulsive buying) akibat adanya rangsangan lingkungan belanja. Implikasi dari lingkungan belanja terhadap perilaku pembelian mendukung asumsi bahwa jasa layanan fisik menyediakan lingkungan yang mempengaruhi perilaku konsumen, dihubungkan dengan karakteristik lingkungan konsumsi fisik (Bitner, Booms, dan Tetreault, 1990).

Menurut penelitian Engel (1995), pembelian berdasar impulse mungkin memiliki satu atau lebih karakteristik ini (p. 156):

a. Spontanitas. Pembelian ini tidak diharapkan dan memotivasi konsumen untuk membeli sekarang, sering sebagai respons terhadap stimulasi visual yang langsung di tempat penjualan.

b. Kekuatan, kompulsi, dan intensitas. Mungkin ada motivasi untuk mengesampingkan semua yang lain dan bertindak dengan seketika.

c. Kegairahan dan stimulasi. Desakan mendadak untuk membeli sering disertai dengan emosi yang dicirikan sebagai "menggairahkan", "menggetarkan," atau "liar."

d. Ketidakpedulian akan akibat. Desakan untuk membeli dapat menjadi begitu sulit ditolak sehingga akibat yang mungkin negatif diabaikan. 


\section{Tipe-tipe Impulse Buying}

Berdasarkan penelitian yang dilakukan sebelumnya, pembelian yang tidak terencana (impulse buying) dapat diklasifasikan dalam empat tipe: planned impulse buying, reminded impulse buying, suggestion impulse buying, dan pure impulse buying (Miller, 2002; Stern, 1962; yang dikutip dalam Hodge, 2004).

a. Pure Impulse Buying merupakan pembelian secara impulse yang dilakukan karena adanya luapan emosi dari konsumen sehinga melakukan pembelian terhadap produk di luar kebiasaan pembeliannya.

b. Reminder Impulse Buying merupakan pembelian yang terjadi karen konsumen tiba-tiba teringat untuk melakukan pembelian produk tersebut. Dengan demikian konsumen telah pernah melakukan pembelian sebelumnya atau telah pernah melihat produk tersebut dalam iklan.

c. Suggestion Impulse Buying merupakan pembelian yang terjadi pada saat konsumen melihat produk, melihat tata cara pemakaian atau kegunaannya, dan memutuskan untuk melakukan pembelian..

d. Planned Impulse Buying merupakan pembelian yang terjadi ketika konsumen membeli produk berdasarkan harga spesial dan produk-produk tertentu. Dengan demikian planned impulse buying merupakan pembelian yang dilakukan tanpa direncanakan dan tidak tengah memerlukannya dengan segera.

\section{Hubungan Antar Konsep}

Pakaian merupakan kulit luar yang menegaskan identitas kita kepada lingkungan sosial, pakaian menjadi media efektif untuk menunjukan status, kedudukan, kekuasaan, lifestyle dari masa ke masa dan shopping menjadi salah satu lifestyle yang paling digemari, untuk memenuhi lifestyle ini masyarakat rela mengorbankan sesuatu demi mencapainya dan hal tersebut cenderung mengakibatkan impulse buying. Ketika terjadi pembelian impulsif akan memberikan pengalaman emosional lebih dari pada rasional, sehingga tidak dilihat sebagai suatu sugesti, dengan dasar ini maka pembelian impulsif lebih dipandang sebagai keputusan rasional dibanding irasional dan hubungan sembilan karakteristik produk yang mungkin dapat mempengaruhi pembelian impulsif, yaitu harga rendah, kebutuhan tambahan produk atau merk, distribusi massa, self service, iklan massa, display produk yang menonjol, umur produk yang pendek, ukuran kecil, dan mudah disimpan.

Pakaian sangat terkait dengan keterlibatan ke karakteristik pribadi (yakni perempuan dan muda) dan pengetahuan tentang fashion, yang pada gilirannya dipengaruhi oleh keyakinan konsumen dalam membuat keputusan pembelian. Selain itu, hubungan yang positif antara tingkat keterlibatan dan mode pembelian pakaian adalah konsumen dengan high fahion involvement lebih menyukai kepada pembelian pakaian.Oleh karena itu, diasumsikan bahwa konsumen dengan higher fashion involvement lebih menyukai menggunakan fashion oriented impulse buying.

\section{Model Pemikiran}

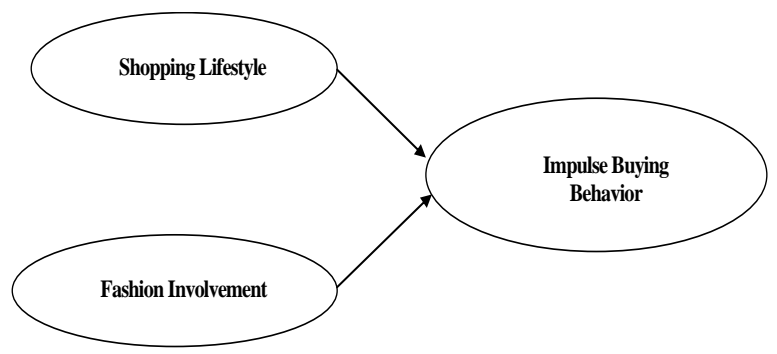

\section{Hipotesis Penelitian}

a. Terdapat pengaruh antara shopping lifestyle dan fashion involvement terhadap impulse buying behavior.

\section{METODE PENELITIAN}

\section{Definisi Operasional Variabel Penelitian}

a. Shopping Lifestyle (X1) merupakan gaya hidup customer pada kategori fashion (seperti pakaian) yang diukur melalui indikator:

- Setiap tawaran iklan mengenai produk fashion, saya cenderung menanggapi untuk membelinya

- Saya cenderung membeli pakaian model terbaru ketika saya melihatnya di Surabaya

- Saya cenderung berbelanja fashion merek terkenal

- Saya yakin bahwa merk produk fashion terkenal yang saya beli terbaik dalam hal kualitas

- Saya sering membeli berbagai merk fashion yang berbeda daripada merk yang biasa saya beli

- Saya yakin ada fashion merk lain yang sama kualitasnya seperti yang saya beli

b. Fashion Involvement (X2) merupakan ketertarikan perhatian pelanggan pada kategori fashion yang diukur melalui pernyataan:

- Saya mempunyai satu atau lebih pakaian dengan model yang terbaru (trend) 
- Fashion adalah satu hal penting yang mendukung aktifitas saya

- Saya lebih suka apabila model pakaian yang saya gunakan berbeda dengan yang lain

- Pakaian yang saya miliki menunjukkan karakteristik saya

- Saya dapat mengetahui banyak tentang seseorang dari pakaian yang digunakan

- Ketika saya memakai pakaian favorit saya, orang lain melihat akan melihat ke arah saya

- Saya cenderung untuk mencoba produk fashion terlebih dahulu sebelum membelinya

- Saya cenderung lebih mengetahui adanya fashion terbaru dibandingkan dengan orang lain

c. Impulse Buying (Y) adalah pembelian yang tidak direncanakan, dimana karakteristiknya adalah pengambilan keputusannya dilakukan dalam waktu yang relatif cepat; dan adanya keinginan untuk memiliki secara cepat. Variabel ini diukur dengan indikator:

- Bila ada tawaran khusus, saya cenderung berbelanja banyak

- Saya cenderung membeli pakaian model terbaru walaupun mungkin tidak sesuai dengan saya

- Saat berbelanja produk fashion, saya cenderung berbelanja tanpa berpikir panjang dulu sebelumnya

- Setelah memasuki shopping center, saya segera memasuki sebuah toko fashion untuk membeli sesuatu

- Saya cenderung terobsesi untuk membelanjakan uang yang saya bawa sebagian atau seluruhnya untuk produk fashion

- Saya cenderung membeli produk fashion meskipun saya tidak begitu membutuhkannya

\section{Metode dan Instrumen Pengumpulan Data}

Metode pengumpulan data ialah teknik atau cara-cara yang dapat digunakan oleh peneliti untuk mengumpulkan data. Metode menunjuk suatu kata yang abstrak dan tidak diwujudkan dalam benda, tetapi hanya dapat dilihatkan penggunaannya melalui angket, wawancara, pengamatan, uji tes, dokumentasi, dan lainnya. Dalam penelitian ini, metode pengumpulan data dilakukan dengan menggunakan angket. Instrumen yang digunakan adalah questionnaire.

Kuisioner dari penelitian ini merupakan kuisioner yang menggunakan skala Likert, untuk mengklasifikasi variable-variabel yang akan diukur dalam penelitian tersebut. Skala Likert ini biasa digunakan untuk mengukur sikap, pendapat, dan persepsi seseorang atau kelompok tentang kejadian atau gejala social. Dengan menggunakan skala Likert, maka variabel yang diukur dan dijabarkan menjadi subvariabel, kemudian sub-variabel dijabarkan lagi menjadi indicator-indikator yang dapat diukur. Akhirnya indicator-indikator yang dapat terukur ini dapat dijadikan titik tolak untuk membuat item instrument yang berupa pertanyaan ataun pertanyaan yang perlu dijawab oleh responden (Riduwan, 2004, p. 86). Penyebaran kuisioner dilakukan pada bulan Mei 2011-Juli 2011.

\section{Populasi Penelitian}

Menurut Kuncoro (2003) populasi adalah kelompok yang lengkap, yang biasanya dapat berupa orang, obyek, transaksi, ataupun kejadian dimana peneliti tertarik dan ingin untuk menjadikannya obyek penelitian (p.103). Populasi dari penelitian ini adalah seluruh masyarakat high income Surabaya.

\section{Teknik Penarikan Sampel}

Sebuah sampel adalah bagian dari populasi. Teknik penentuan sampel adalah dengan metode non probability sampling (Nasir, 1999, p. 325) Jenis metode non probability sampling yang digunakan adalah judgemental sampling yaitu memberikan batasan-batasan tentang responden yang memenuhi kriteria sebagai berikut:

- Responden tinggal di Surabaya

- Responden memiliki pendapatan sendiri

- Responden memiliki pengeluaran $\geq R p$ 1,250,000

- Responden pernah berbelanja di Galaxy Mall, Lend mark dan Grand City

Jumlah responden didapatkan dengan menggunakan rumus Yamane yang melakukan penentuan ukuran sampel didasarkan atas kesalahan 10\% dengan kepercayaan 95\% terhadap populasi. Penentuan jumlah sampel dengan menggunakan rumus Yamane dipilih karena praktis dan telah terbukti keakuratannya. Rumus Yamane adalah sebagai berikut:

$$
\mathrm{n}=\frac{\mathrm{N}}{\mathrm{N}(\mathrm{d})^{2}+1}
$$

Keterangan:

$\mathrm{n}$ : jumlah sampel yang dicari

N : Ukuran Populasi (Jumlah penduduk Surabaya Usia 15 tahun ke atas yang bekerja $=1,250,690$ ) (Sumber: BPS Propinsi Jawa Timur, Sakernas dan Susenas Tahun 2004-2009). 
d : nilai presisi (dalam penelitian ini, peneliti memilih taraf signifikansi 10\%).

Berdasarkan rumus tersebut dan dengan menggunakan beberapa asumsi tertentu, Yamane dapat membuat tabel dengan perhitungan sebagai berikut:

$\mathrm{n}=\frac{\mathrm{N}}{\mathrm{N}(\mathrm{d})^{2}+1}$

$\mathrm{n}=\frac{1,250,690}{1,250,690(0.1)^{2}+1}$

$\mathrm{n}=\frac{1,250,690}{12,507.9}$

$\mathrm{n}=99.9920$ yang dibulatkan menjadi 100 responden

\section{Metode Analisa Data}

\section{a. Analisis Regresi Linier Berganda}

Analisis Regresi Linier Berganda digunakan untuk mengetahui pengaruh yang diberikan oleh variabel bebas terhadap variabel terikat. Formula yang digunakan adalah:

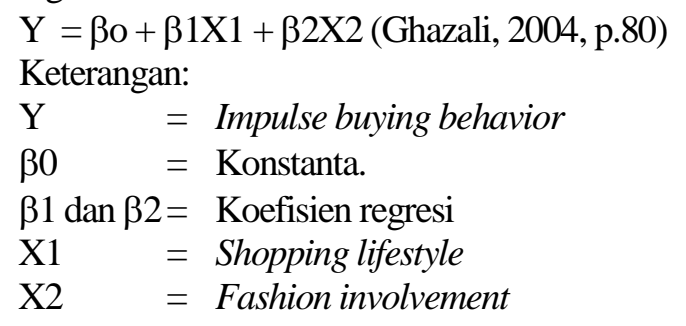

\section{b. Pengujian Hipotesis}

Pengujian hipotesis dilakukan dengan menggunakan uji $\mathrm{F}$ dan uji t

- Uji F

Pengujian ini bertujuan untuk mengetahui sejauh mana variasi variabel bebas yang digunakan mampu menjelaskan variabel tergantungnya. Dapat juga diartikan apakah model regresi linier berganda yang digunakan sesuai atau tidak

- Uji t (Pengujian Parsial)

Uji $t$ bertujuan untuk melihat pengaruh variabel bebas secara parsial (sendiri-sendiri) terhadap variabel terikat. Untuk mengetahui apakah ada pengaruh secara parsial variabel bebas terhadap variabel terikat

\section{Uji Asumsi Klasik}

\section{Uji Multikolonieritas}

- Uji Multikolonieritas bertujuan untuk menguji apakah model regresi ditemukan adanya korelasi antar variabel bebas (independen).

\section{Uji Heteroskedastisitas}

- Uji heteroskedastisitas bertujuan menguji apakah dalam model regresi terjadi ketidaksamaan variance dari residual satu pengamatan ke pengamatan yang lain. Jika variance dari residual satu pengamatan ke pengamatan lain tetap, maka disebut homoskedastisitas dan jika berbeda disebut heteroskedastisitas.

\section{Uji Normalitas}

- Uji normalitas bertujuan untuk menguji apakah dalam model regresi, variabel pengganggu atau residual memiliki distribusi normal. Seperti diketahui bahwa uji t dan F mengasumsikan bahwa nilai residual mengikuti distribusi normal.

\section{ANALISA DATA}

Deskripsi Tanggapan Responden Terhadap Variabel Bebas dan Variabel Terikat

\section{a. Shopping Lifestyle $\left(\mathrm{X}_{1}\right)$}

Tabel 1. Tanggapan Responden Mengenai Shopping lifestyle

\begin{tabular}{lll}
\hline Indikator & BTB (\%) & TTB (\%) \\
\hline Tawaran iklan & $28,2 \%$ & $71,8 \%$ \\
Model terbaru & $16,4 \%$ & $83,6 \%$ \\
Merk terkenal & $27,3 \%$ & $70,0 \%$ \\
Kualitas terbaik & $11,8 \%$ & $88,2 \%$ \\
Beli merk berbeda & $14,5 \%$ & $85,5 \%$ \\
Merk lain sama & $13,6 \%$ & $86,4 \%$ \\
\hline
\end{tabular}

Tabel 1 menunjukkan bahwa sebagian besar responden memberikan penilaian yang baik terhadap atribut-atribut shoping lifestyle. Hal ini mencerminkan bahwa shopping lifestyle yang terdiri dari setiap tawaran iklan mengenai produk fashion, saya cenderung menanggapi untuk membelinya, cenderung membeli pakaian model terbaru ketika saya melihatnya di shopping center Surabaya, cenderung berbelanja fashion merk terkenal, yakin bahwa merk produk fashion terkenal yang saya beli terbaik dalam hal kualitas, sering membeli berbagai merk fashion yang berbeda daripada merk yang biasa saya beli dan yakin ada fashion merk lain yang sama kualitasnya seperti yang saya beli dapat mempengaruhi responden untuk melakukan impulse buying.

\section{b. Fashion Involvement $\left(\mathrm{X}_{2}\right)$}

Tabel 2 menunjukkan bahwa sebagian besar responden memberikan penilaian yang baik terhadap atribut-atribut fashion involvement. Hal ini mencermin- 
kan bahwa fashion involvement yang terdiri dari mempunyai satu atau lebih pakaian dengan model yang terbaru (trend), Fashion adalah satu hal penting yang mendukung aktifitas, lebih suka apabila model pakaian yang saya gunakan berbeda dengan yang lain, Pakaian yang saya miliki menunjukkan karakteristik, mengetahui banyak tentang seseorang dari pakaian yang digunakan, memakai pakaian favorit saya, orang lain melihat akan melihat ke arah saya, cenderung untuk mencoba produk fashion terlebih dahulu sebelum membelinya, dan cenderung lebih mengetahui adanya fashion terbaru dibandingkan dengan orang lain dapat mempengaruhi responden untuk melakukan impulse buying.

Tabel 2. Tanggapan Responden Mengenai Fashion Involvement

\begin{tabular}{lcl}
\hline Indikator & BTB $(\%)$ & TTB $(\%)$ \\
\hline Trend & 7,3 & 92,7 \\
Fashion hal penting & 7,3 & 94,5 \\
Berbeda dari yang lain & 7,3 & 92,7 \\
Karakteristik saya & 5,5 & 94,5 \\
Mengetahui orang & 16,4 & 83,6 \\
Orang melihat saya & 10,0 & 90,0 \\
Mencoba terlebih dulu & 7,3 & 92,7 \\
Tahu fashion terbaru & 12,7 & 87,3 \\
\hline
\end{tabular}

Sumber: Lampiran

\section{c. Impulse Buying (Y)}

Tabel 3. Tanggapan Responden Mengenai Impulse Buying

\begin{tabular}{lll}
\hline Indikator & BTB (\%) & TTB (\%) \\
\hline Tawaran khusus & $20,9 \%$ & $79,1 \%$ \\
Model terbaru & $62,7 \%$ & $37,3 \%$ \\
Tanpa berpikir & $50,0 \%$ & $50,0 \%$ \\
Langsung memasuki & $50,0 \%$ & $50,0 \%$ \\
Terobsesi berbelanja & $50,0 \%$ & $50,0 \%$ \\
Tidak butuh & $42,7 \%$ & $57,3 \%$ \\
\hline
\end{tabular}

Sumber: Lampiran

Tabel 3 menunjukkan bahwa sebagian besar responden memberikan penilaian yang cukup baik terhadap atribut-atribut impulse buying. Hal ini mencerminkan bahwa impulse buying yang terdiri dari bila ada tawaran khusus, saya cenderung berbelanja banyak, cenderung membeli pakaian model terbaru walaupun mungkin tidak sesuai dengan saya, saat berbelanja produk fashion, saya cenderung berbelanja tanpa berpikir panjang dulu sebelumnya, setelah memasuki Shopping center, saya langsung memasuki sebuah toko fashion untuk membeli sesuatu, cenderung terobsesi untuk membelanjakan uang yang saya bawa sebagian atau seluruhnya untuk produk fashion dan cenderung membeli produk fashion meskipun saya tidak begitu membutuhkannya tidak semuanya disetujui oleh responden.

\section{Analisa Regresi Linier Berganda}

\section{Uji Asumsi Klasik}

Multikolinieritas

\section{Tabel 4. Hasil Uji Multikolinieritas}

\begin{tabular}{ll}
\hline Variabel Bebas & VIF \\
\hline Shopping Lifestyle & 1.163 \\
Fashion Involvement & 1.163 \\
\hline
\end{tabular}

Berdasarkan Tabel 4 dapat dilihat bahwa nilai VIF untuk variabel shopping lifestyle dan fashion involvement semuanya kurang dari 10 , hal ini mengindikasikan tidak terjadi multikolinieritas sehingga asumsi non multikolinieritas terpenuhi.

Heteroskedastisitas

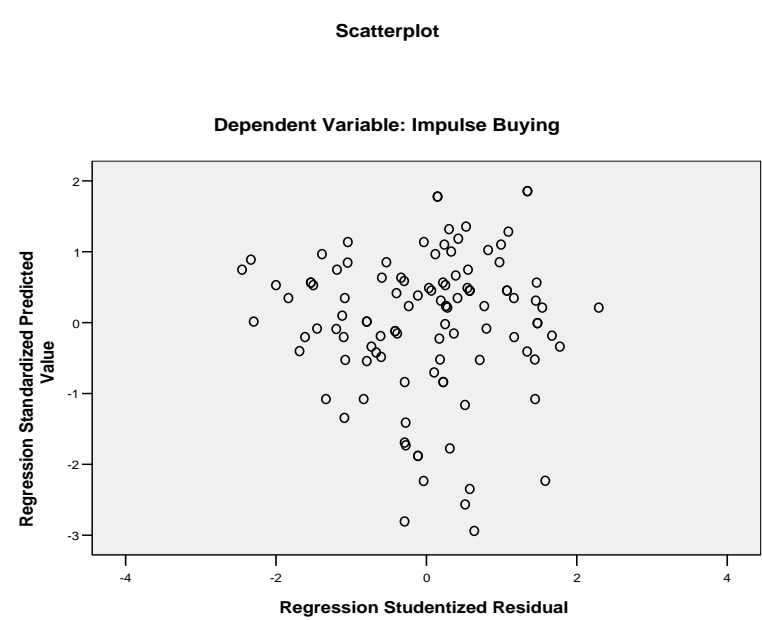

Gambar 1. Grafik Plot Antara ZPRED dengan SRESID

Grafik plot pada Gambar 1 menunjukkan tidak ada pola yang jelas, serta titik-titik menyebar di atas dan di bawah angka 0 pada sumbu Y. Berdasarkan hasil tersebut maka dapat disimpulkan bahwa tidak terjadi heteroskedastisitas, sehingga asumsi non heteroskedastisitas terpenuhi.

\section{Normalitas}

Pada Gambar 2 dapat dilihat bahwa residual menyebar di sekitar garis diagonal dan mengikuti arah garis diagonal, dan diambil kesimpulan bahwa model regresi memenuhi asumsi normalitas. 
Normal P-P Plot of Regression Standardized Residual

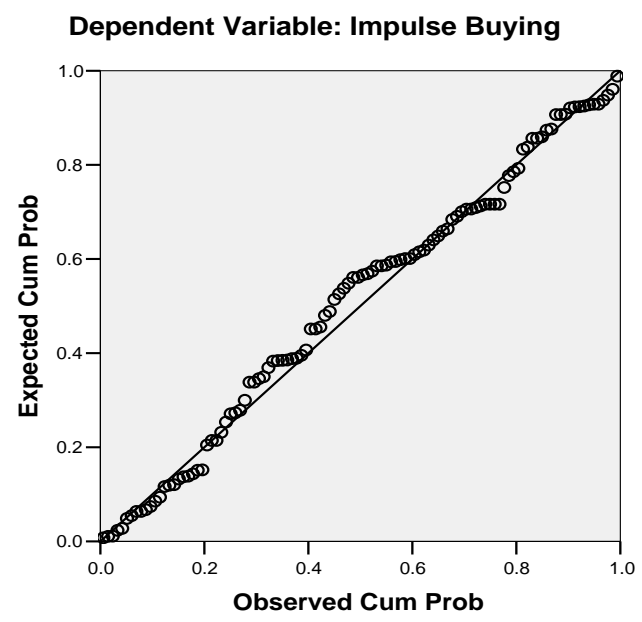

Gambar 2. Grafik Normal Probability Plot

\section{Analisis Model}

Berikut ini adalah hasil analisis regresi linier berganda seperti pada Tabel 5 .

Tabel 5. Hasil Analisis Regresi Linier Berganda

\begin{tabular}{llll}
\hline Model & Koefisien & t & Sig. t \\
\hline Konstanta & -1.456 & & \\
Shopping Lifestyle (X1) & 0.636 & 6.243 & 0.000 \\
Fashion Involvement $(\mathrm{X} 2)$ & 0.518 & 3.971 & 0.000 \\
R & $=0.666$ & & \\
R Square & $=0.443$ & & \\
F & $=42.612$ & & \\
Sig. F & $=0.000$ & & \\
\hline
\end{tabular}

Ringkasan hasil analisis regresi linier berganda pada Tabel 5 diuraikan sebagai berikut:

a. Koefisien regresi $\left(\beta_{\mathrm{i}}\right)$

1. Tanda positif pada nilai koefisien regresi melambangkan hubungan yang searah antara $\mathrm{X}_{1}$ dan $\mathrm{Y}$, artinya apabila shopping lifestyle responden semakin tinggi, maka impulse buying responden juga akan mengalami peningkatan dengan variabel lainnya tetap.

2. Tanda positif pada nilai koefisien regresi melambangkan hubungan yang searah antara $\mathrm{X}_{2}$ dan $\mathrm{Y}$, artinya apabila fashion involvement responden semakin tinggi, maka impulse buying responden juga akan mengalami peningkatan variabel lainnya tetap.

\section{Koefisien Determinasi}

Koefisien Determinasi $\left(\mathrm{R}^{2}\right)$ sebesar 0.443 yang memiliki arti bahwa peran variabel bebas $X_{1}$ dan $X_{2}$ untuk menjelaskan variabel terikat $\mathrm{Y}$ adalah sebesar 44.3\% dan sisanya $55.7 \%$ dijelaskan oleh variabel lain di luar variabel bebas yang digunakan dalam penelitian ini.

\section{Koefisien Korelasi}

Koefisien korelasi (R) sebesar 0.666 menunjukkan bahwa hubungan variabel bebas X1 dan X2 dengan variabel terikat $Y$ adalah kuat. Nilai koefisien $\mathrm{R}$ yang positif menunjukkan pengaruh hubungan yang searah atau jika nilai variabel bebas naik maka nilai variabel terikat juga naik.

\section{Pembuktian Hipotesis}

\section{Uji F}

Berdasarkan nilai statistik pada Tabel 5 dapat dilihat bahwa nilai $\mathrm{F}$ hitung $=42.612$. Nilai $\mathrm{F}$ table $(\mathrm{df1}=2 ; \mathrm{df} 2=107)$ adalah 3.081. Nilai $\mathrm{F}$ hitung $>\mathrm{F}$ table, maka $\mathrm{H}_{0}$ ditolak dan $\mathrm{H}_{1}$ diterima dan dapat disimpulkan bahwa variabel bebas $\mathrm{X}_{1}$ dan $\mathrm{X}_{2}$ secara simultan (bersama-sama) berpengaruh signifikan terhadap variabel terikat $(\mathrm{Y})$.

Dari hasil uji F di atas maka disimpulkan untuk menolak hipotesis nol. Dengan demikian hipotesis penelitian diterima, dengan kata lain shopping lifestyle dan fashion involvement secara simultan (bersamasama) mempunyai pengaruh besar terhadap impulse buying responden.

\section{Uji t}

Pada Tabel 5 diketahui untuk variabel shopping lifestyle nilai $\mathrm{t}$ hitung adalah 6.243, nilai $\mathrm{t}$ tabel $(\mathrm{df}=107 ; \alpha=0.05 / 2)=1.982$. Nilai t hitung $>$ nilai $\mathrm{t}$ tabel, maka disimpulkan bahwa shopping lifestyle secara parsial (sendiri-sendiri) mempunyai pengaruh signifikan terhadap impulse buying responden. Hal ini berarti peningkatan atau penurunan variabel shopping lifestyle yang dilakukan responden memberikan pengaruh besar terhadap impulse buying .

Pada Tabel 5 diketahui untuk variabel fashion involvement nilai thitung adalah 3.971, nilai t tabel $(\mathrm{df}=107 ; \alpha=0.05 / 2)=1.982$. Nilai t hitung $>$ nilai $\mathrm{t}$ tabel, maka disimpulkan bahwa fashion involvement secara parsial (sendiri-sendiri) mempunyai pengaruh signifikan terhadap impulse buying. Hal ini berarti peningkatan atau penurunan variabel fashion involvement yang dilakukan responden memberikan pengaruh besar terhadap impulse buying . 


\section{Koefisien Determinasi Parsial}

Tabel 6. Kuadrat Koefisien Korelasi Parsial

\begin{tabular}{lll}
\hline Variabel & $\mathbf{r}$ & $\mathbf{r}^{\mathbf{2}}$ \\
\hline Shopping Lifestyle & 0.517 & 0.267 \\
Fashion Involvement & 0.358 & 0.128 \\
\hline
\end{tabular}

Sumber: Lampiran

Variabel yang mempunyai pengaruh paling dominan terhadap impulse buying adalah yang nilai kuadrat korelasi parsialnya terbesar. Dari 2 variabel bebas diketahui bahwa variabel shopping lifestyle mempunyai nilai kuadrat korelasi parsial terbesar yaitu 0.267 , yang artinya bahwa variabel shopping lifestyle mempengaruhi impulse buying paling besar dibanding variabel yang lain, yaitu sebesar $26.7 \%$

\section{KESIMPULAN DAN SARAN}

\section{Kesimpulan}

Berdasarkan pada hasil pembahasan mengenai shopping lifestyle, fashion involvement terhadap impulse buying behavior, dapat disimpulkan beberapa hal yaitu:

a. Shopping lifestyle berpengaruh signifikan terhadap impulse buying behavior pada masyarakat high income di Galaxy Mall Surabaya

b. Fashion involvement berpengaruh signifikan terhadap impulse buying behavior pada masyarakat high income di Galaxy Mall Surabaya

c. Shopping lifestyle memiliki pengaruh yang paling dominan diantara variabel lain yang ada terhadap impulse buying behavior pada masyarakat high income di Galaxy Mall Surabaya

\section{Saran}

Berdasarkan kesimpulan yang diperoleh, maka penulis memberikan saran-saran bagi pihak-pihak yang berkepentingan dalam penelitian ini, antara lain:

a. Hendaknya fashion involvement selalu diperhatikan dengan memberikan masukan tentang produk fashion yang sesuai karakteristik pengunjung karena dapat mempengaruhi impulse buying behavior pada masyarakat high income di Galaxy Mall Surabaya.

b. Shopping lifestyle hendaknya terus dipertahankan oleh pihak Galaxy Mall Surabaya dengan tetap menjaga kualitas terbaik dari merk produk fashion karena variabel tersebut merupakan variabel dominan dalam mempengaruhi impulse buying behavior pada masyarakat high income di Galaxy Mall Surabaya. c. Bagi peneliti lain dapat melakukan penelitian dengan topik sama, namun perlu menambahkan faktor lain seperti pre-decision stage dan postdecision stage karena dari hasil penelitian ini masih dipengaruhi oleh faktor-faktor lain.

\section{DAFTAR PUSTAKA}

Andrew, M., 1979, Involvement: A potentially important mediator of consumer behavior. In advances in consumer research, ed. William L. Wilkie, 6 (Provo, Utah: Association for Consumer Research), pp. 191-196.

Bayley, G. \& Nancarrow, C., 1998, Impulse purchasing: a qualitative exploration of the phenolmenon. Qualitative market research: An Internatinal Journal, 1(2), pp. 99-114.

Benjamin D.Z. \& Kanter, M.R., 1976, The differentiation of life-styles. Annual Reviews of Sociology, pp. 269-297.

Browne, B.A. \& Kaldenberg, D.O., 1997, Conceptualizing self-monitoring: links to meterialism and product involvement, Journal of Consumer Marketing, 14(1), pp. 31-44.

Cobb J.C. \& Hoyer W.D., 1986, Planned versus impulse purchase behaviour. Journal of Retailing, 62(4), pp. 384-409.

Douglas, M.T. \& Baron, C., Isherwood, 1979, The world of goods, (New York: Basic Books).

Engel, James F., Blackwell, R.D. \& Miniard, P.W., 1995, Perilaku konsumen, Jilid 1 (Edisi keenam), Jakarta: Binarupa Aksara.

Fairhurst, A.E., Good, L.K. \& Gentry, J.W., 1989, Fashion involvement: an instrument validation procedure. Clothing and Textiles Research journal, 7(3), pp. 10-14.

Flynn, L. \& Goldsmith, R., 1993, A causal model of consumer involvement: replication and critique, Journal of Social Behavior and Personality, 8(6), pp. 129-42.

Goldsmith, R.E. \& Emmert, J., 1991, Measuring product category involvement: a multitraitmultimethod study, Journal of Business Research, 23(4), pp. 363-71.

Hatane, S., 2005, Respons lingkungan berbelanja sebagai stimulus pembelian, Journal Manajemen dan Kewirausahaan, 7(2), pp. 152-170.

Hausman, A., 2000, A multi- method investigation of consumer motivations in impulse buying behavior, Journal of Consumer Marketing, 17(15), pp. 403-419.

Kacen, J.J., \& Lee, J.A., 2002, The influence of culture on consumer impulsive buying behavior, Journal of Consumer Psychology,12(2), pp. 163-76. 
Kapferer, J.N. \& Laurent, G., 1985, Measuring consumer involvement profile, Journal of Marketing. 22(1), pp. 41-53.

Kim, H., 2005, Consumer profiles of apparel product involvement and values. Journal of Fashion Marketing and Management, 9(2), pp. 207220.

Kollat, D.T. \& Willett, Ronald, P., Februari 1967, Customer Impulse Purchasing Behavior, Journal of Marketing Research, 4(2), pp. 21-31.

Kotler, Philip, \& Amstrong, G., 2004, Dasar-dasar Pemasaran, Bagian 1, Jakarta: Prenhallindo.

Martin, C., 1998, Relationship marketing: a highinvolvement product attribute approach. Journal of Product and Brand Management, 7(1), 6-26.

Mowen, J.C. \& Minor, M., 2002, Consumer behaviour $\left(5^{\text {th }}\right.$ Edition) Upper saddle river: Pretience Hall, Inc.

O'Cass, A., 2004, Fashion clothing consumption: antecedents and consequences of fashion clothing involvement, European Journal of Marketing, 38(7), pp. 869-82.

Park, Joo, Kim \& Forney, 2005, A structural model of fashion oriented impulse buying behavior, Journal of Fashion Marketing and Management, 10(4), 433-446.

Prayoga, L., 2008 March 12, Mall untuk wisata, Kenapa Tidak?, Indonesia Tourism News, 11.
Prima, G.A., 2009, January 30). Anchor tenant, from http://www.griya.asri.prima.mht.

Richard, L.C. \& Jerry, C.O., September 1988, The role of involvement in attention and comprehension processes, Journal of Consumer Research, 15(9), pp. 210-224.

Ronald, W.S., 1995, Studi kelayakan galaxy mall ditinjau dari aspek pasar dan keuangan, (TA No. 419/EM/1995). Unpublished undergraduate thesis, Universitas Kristen Petra, Surabaya.

Rook, D.W. and Fisher, R.J., 1995, Normative influence on impulse buying behavior, Journal of Consumer Research, 22, pp. 305-313.

Seo, J., Hathcote, J.M. and Sweaney, A.L., 2001, Casualwear shopping behavior of college men in Georgia, USA, Journal of Fashion Marketing and Management, 5(3), pp. 208-222.

Stern, H., April 1962, The significance of impulse buying today, Journal of Marketing, Vol. 26(4), pp. 59-62.

Tan, L., April 2009, The new way of lifestyle, Grand Indonesia Magazine, 4.

Zaichkowsky, J.L., Desember 1985, Measuring the Involvement Construct in Marketing. Journal of Consumer Research, 12(12), pp. 341-352.

Zumar, D., March 2009, 82 Persen, Konsumen Doyan Sambangi Mal. Retrieved April 01, 2009, from http://www.pewarta-kabarindonesia.blogspot.com. 